\title{
The variations of physico-chemical parameters during summer in Lake Erenciuc from the Danube Delta (Romania)
}

\author{
Gheorghe Romanescu $^{1 \star}$, Alin Mihu-Pintilie ${ }^{2}$, Cristian Trifanov ${ }^{3}$, Cristian C. Stoleriu ${ }^{1}$ \\ ${ }^{1}$ Alexandru Ioan Cuza University of Iasi, Faculty of Geography and Geology, Department of Geography, Carol I 20A, 700505 Iasi, \\ Romania, e-mail: romanescugheorghe@gmail.com ( ${ }^{*}$ corresponding author) \\ ${ }^{2}$ Alexandru Ioan Cuza University of Iasi, Interdisciplinary Research Department - Field Science, Lascar Catargi 54, 700107 Iasi, Romania \\ ${ }^{3}$ Danube Delta National Institute for Research and Development, 820112 Tulcea, Romania
}

\begin{abstract}
Lake Erenciuc is situated in the Danube Delta (Romania) and was created in the abandoned riverbed of the Sfântu Gheorghe arm. It is the largest meander lake in Romania. During spring-summer, the physico-chemical parameters of water have been measured in seven lake sampling points and one at the Sfântu Gheorghe branch, which supplies the lake through Erenciuc channel. The area around Lake Erenciuc belongs to the category of strictly protected areas within the Danube Delta Biosphere Reserve. The following water quality parameters were measured: temperature $\left(\mathrm{T}:{ }^{\circ} \mathrm{C}\right) ; \mathrm{pH}$ ( $\mathrm{pH}$ units); Luminescent Dissolved Oxygen (LDO: $\mathrm{mg} \mathrm{dm}^{-3}$ ); Dissolved Oxygen saturation (DO: \%); water tension (U: $\mathrm{mV}$ ); Electrical Conductivity (EC: $\mu \mathrm{S} \mathrm{cm}^{-1}$ ); Total Dissolved Solids concentration (TDS: $\mathrm{mg}$ dm ${ }^{-3}$ ). The recorded values are easily differentiated across the entire length of the elongated lake path, especially between inflow (upstream) and outflow (downstream). The parameters recorded during the spring-summer period, with high flow rates and high water levels, demonstrate good lake water quality, especially oxygenation. The study also demonstrates that high waters refresh and recalibrate the water quality in isolated lake basins.
\end{abstract}

Key words: bathymetry, management, physico-chemical properties, natural reserve, palustrine vegetation

\section{Introduction}

The Danube Delta has a surface of $5600 \mathrm{~km}^{2}$, being the third delta in Europe after the Volga and Kuban Deltas (Russian Federation). It represents the creation of the Danube River in the north-west sector of the Black Sea (Romanescu 2005). It has a particular coastline dynamic, advancing at the mouths, while between the branches it is subject to erosion processes. These are specific phenomena for most of the world's deltas as a consequence of decreasing river solid flows and the increasing water level of the planetary oceans (Adopo et al. 2014; Allenbach et al. 2015; Keremedchiev and Valchev 2008; Matenco et al. 2015; Petrişor et al. 2016; Romanescu and Cojocaru 2010; Romanescu 2013; Van Dinter 2017; Vespremeanu-Stroe et al. 2017). It is the only delta on the planet to have been declared a Biosphere Reserve (in 1991). It is spread between three main branches that end with secondary deltas for each river mouth: the Chilia (digitate delta), the Sulina (triangular shape) and the Sfântu Gheorghe (rounded shape) (Romanescu 2013). The oldest tributary is the southern one (Sfântu Gheorghe) which is why two important lakes of abandoned meanders are found along its length: Erenciuc and Belciug Lakes (Romanescu 2005). The most important one is Erenciuc Lake, declared a strictly protected area with full protection status for Erenciuc's Alder forest, (50 ha of protected black alder forest - Alnus glutinosa). The alder forest located at the downstream mouth of the lake also plays a role in the protection of the river levee (Andronache et al. 2017; Petrişor 2016).

The water supply within deltaic systems, in floodplains and particularly in oxbow lakes has been widely studied at an international level. Thus, to date, the following topics have been addressed: (i) implications of water dynamic in the ecological reconstruction of partially or totally closed lakes, such as meander lakes (Driga,2008), (ii) highlighting, by measuring specific electric conductivity, of water volume and sediment mixture during floods within meander lakes (Turk et al. 2016), (iii) analysis of the spatial connectivity and heterogeneity of the aquatic system in river floodplains (Amoros and Bornette 2002; Thoms 2003), (iv) influ- 
ence of flood pulse on the chemical composition and biomass of macrophytes by stressing the increased azoth and phosphorus contents in meander lakes (Camargo and Esteves 1996), ( $v$ ) dynamic of water quality and the role of meander lakes in the multitemporal storage of nutrients from anthropic activities (GlińskaLewczuk 2009), (vi) dynamic of nutrients and organic matter in the floodplains of glacial rivers (Tockner et al. 2002), (vii) management of natural lakes transformed into artificial water bodies through hydrotechnical or dredging interventions (Kubiak et al. 2017; Su et al. 2017; Ten Brinke et al. 2017; Van Leeuven et al. 2016), (viii) GIS techniques for the monitoring of water bodies (Yang et al. 2014).

There are detailed studies at a national level for the Danube Delta and the great wetlands: Balta Ialomitei and Balta Brailei along the lower course of the Danube river (Banaduc et al. 2016; Burada et al. 2014; Catianis et al. 2014; Coops et al. 2008; Navodaru et al. 2001; Raischi et al. 2016). The quality and productivity of the biota within meander lakes localized in deltaic systems within the temperate area constituted the main topic of the studies within which we explain the variation and interdependence between the water flows communicating seasonally between the lotic and the lentic systems. The productivity of the biota is the direct response of the flood pulse inducing a spatial and seasonal variability of water level fluctuation, and of the physical-chemical parameters $(\mathrm{pH}, \mathrm{EC}$, concentration and distribution of oxygen, nutrient availability) (Forsberg 1984; Furch 1984; Junk et al. 1989; Melack 1984; Payne 1986) and biological ones (Affonso et al. 2011; Sioli 1984), as well as of the benefits induced to the floodplain environment (Bayley 1995; Tockner et al. 2000). Dissolved oxygen is an extremely important parameter for maintaining life throughout the aquatic environment (Banaduc et al. 2016; Coops et al. 2008; Navodaru et al. 2001, 2005). Water quality and the influence of the physicochemical parameters on the biota has determined most recent studies to also consider isolated lakes which are not of any particular economic importance but are individualized as biodiversity islands (Anton et al. 2008; Barbulescu 2015; Borowiak 2014; Cudowski et al. 2013; Gadzinowska 2013; Kundrat et al. 2016; Marszelewski et al. 2017; Merecki et al. 2015; Mihu-Pintilie et al. 2014; Pantea et al. 2017; Pasztaleniec et al. 2013; Petrovici et al. 2010; Puri et al. 2010; Romanescu 2003, 2006; Rzymski et al. 2017; Sevian et al. 2015; Sundri 2015; Ureche et al. 2012; Wrzesinski et al. 2015; Wu et al. 2013).

The seasonal dynamic of the water volume within meander lakes determines the generation of their existence phases: filling, inundation, drainage and isolation (e.g. lakes of Parana River valley) (Garcia de Emiliani 1997: after Lewis 1983). In the temperate climate lake, meander lakes localized in floodplains are characterized by the manifestation of three phases: water supply from its catchment basin (limnophase), water supply from a river nearby (potamophase) and its temporary disappearance during the flood (Dawidek and Ferencz 2012).

In conditions of total isolation, the oxbow lakes are doomed. The natural conditions of the Danube Delta lead to an intense organic sedimentation within the water bodies (up to 80\%) (Romanescu 2006). In higher altitude lakes, where the climate is colder, the organic sedimentation is lower (Mihaiescu et al. 2012; Pop et al. 2013). Meander lakes, just before turning into oxbow lakes, that are still connected to the river flow, in this case Sfântu Gheorghe, prolong their lives (Romanescu 2005). For this reason, the secondary distributaries are periodically or constantly dredged or new channels are built for the water to flow freely in between the main river courses. The water level within the great floodplains and the deltas is extremely variable due to the slope, width of the riverbed and the flow conditions (Ashaary et al. 2015; Barbulescu and Barbes 2013; Choi et al. 2016; Dragicevic et al. 2016; Mierlă et al. 2014, 2015; Romanescu and Stoleriu 2014). At higher water levels, the water flows from within the channel towards the lake while at lower water levels it flows in the opposite direction (Romanescu 2005, 2006; Gâstescu and Ştiucă 2008; Yang et al. 2014).

The main physico-chemical properties were targeted in respect to the transitional waters between spring and summer from the largest meander lake left in Romania. Depending on the physico-chemical characteristics of the isolated waters, there is a specific biota growing with alterations from one season to another. From this point of view Lake Erenciuc is a model for supplying, preserving and developing a natural isolated lake environment.

\section{Study area}

The most spectacular meander lakes are located along the Sfântu Gheorghe branch: Erenciuc on the left bank and Belciug on the right bank. The largest surface, and second in respect to depth is Lake Erenciuc: 1.29 $\mathrm{km}^{2}$ and 3-3.5 $\mathrm{m}$ depth. In the central part of the lake the width is $308 \mathrm{~m}$. The general cardinal orientation is $\mathrm{N}-\mathrm{S}$ (Fig. 1). The end of the lake is in the north and the mouth in the south, connecting with the Sfântu Gheorghe branch. The end of the lake is in the upstream of the old route and the mouth in the downstream which links naturally with the main branch (Sfântu Gheorghe). It is the largest meander lake in Romania and it preserves the typical shape of a free meander. The shallowest areas of the lake are present on both sides. In- 

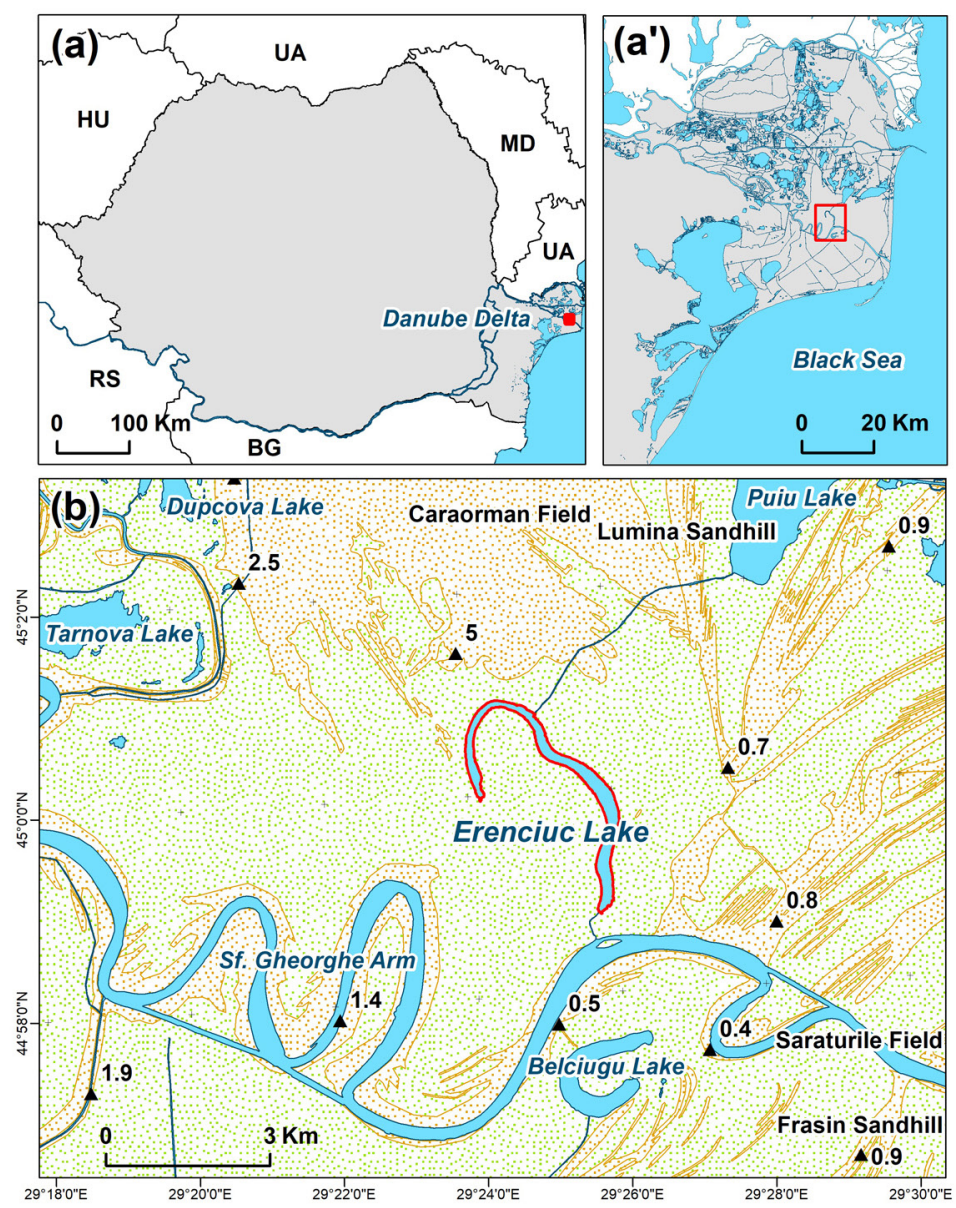

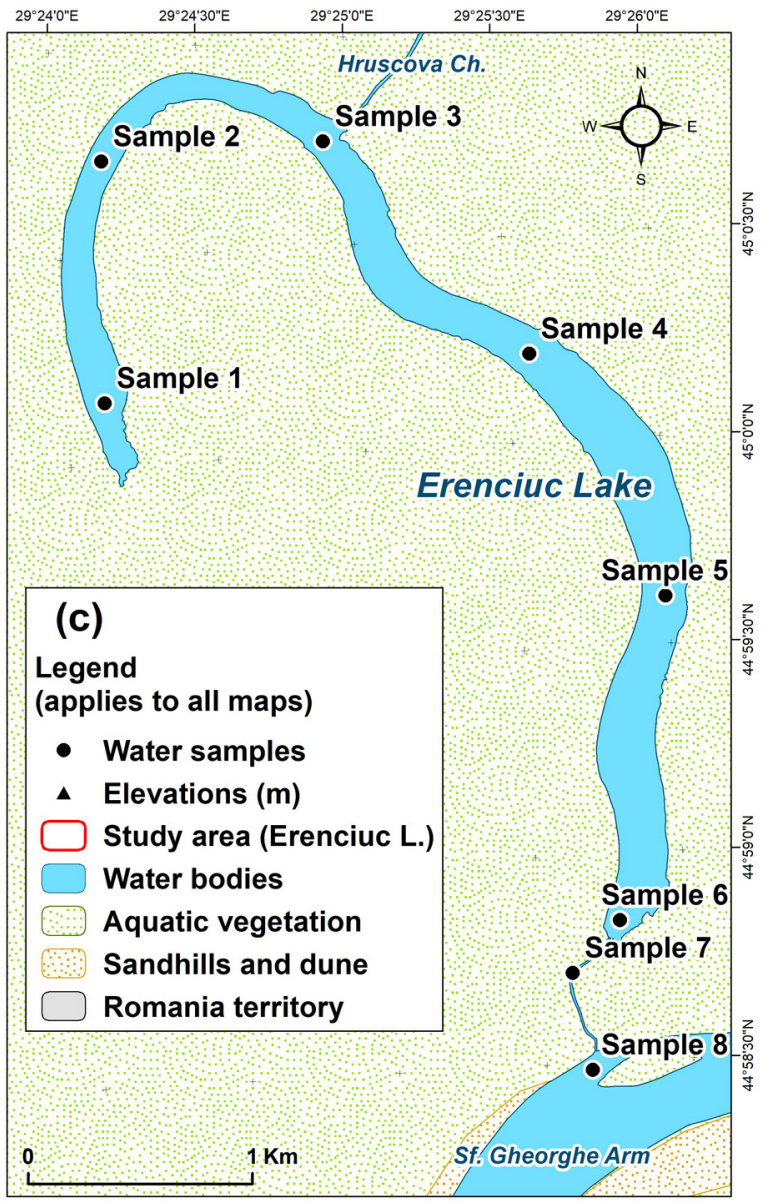

Fig. 1. The geographical location of the study area in Romania (a), within the Danube Delta (a'), at the left bank of the Sfântu Gheorghe branch (b) and distribution of sampling sites in Lake Erenciuc (c)

organic clogging is intense towards downstream while organic clogging is intense upstream.

Lake Erenciuc holds two main inflows and a secondary one, which flows only at high water levels. The most important inflow is the Erenciuc channel (Fig. 2),

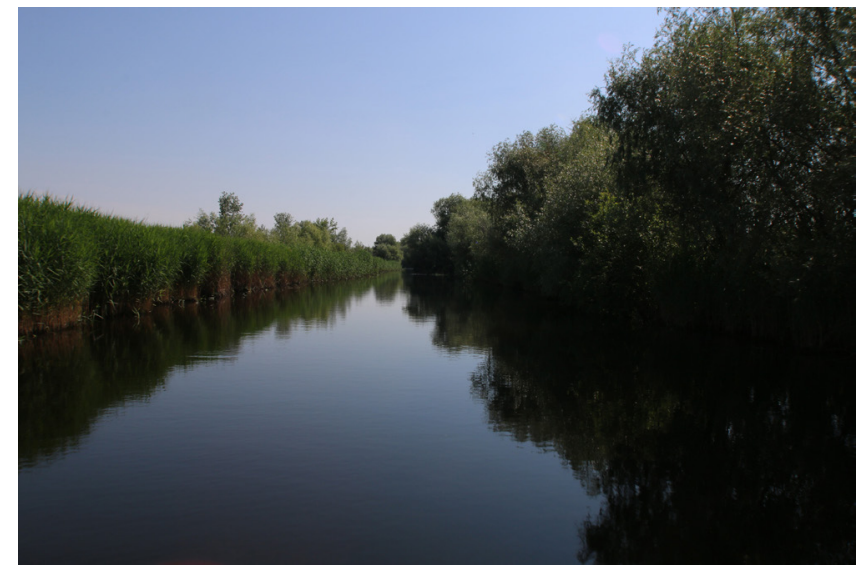

Fig. 2. Erenciuc channel linking the lake with Sfântu Gheorghe branch. View towards the Sfântu Gheorghe branch which links the lake to the Sfântu Gheorghe branch. The Hruscova channel (or Mocansca) links the lake with Puiu lake and further with Rosu and Puisor lakes. The secondary linkage is between Lake Erenciuc and the Magistral channel but at the moment this is heavily clogged and it flows only at very high-water levels.

\section{Methods}

As a result of the fact that the lake has an elongated shape seven sampling sites were established within the lake and one on the main inflow where the water flows towards the lake at the point of sampling. A sample from the Sfântu Gheorghe watercourse is necessary because the collected data corelates with the two nearby samples from the mouth (downstream) of the lake. The sampling sites 2 and 3 reach the maximum depths. The sampling methodology was conducted according to the monitoring manual by the National Administration "Romanian Waters" from Bucharest and also according to the literature models that evaluate water quality (Cical et al. 2016; Cirtina and Capatina 2016, 2017; Dirtu 
et al. 2016; Iordache et al. 2015; Romanescu et al. 2014, 2017; Stefan et al. 2017; Tokar et al. 2016).

The sampling took place in early summer, on $15^{\text {th }}$ of June 2017. The transition values for these parameters are maintained for about 15 days. They correspond with hydrophile vegetation growth and also with fish juveniles that are hatching in the offshore waters.

Water quality was assessed pursuant to the quality standards issued by the Order of the Ministry of Environment and Water Management no. 161/ 2006. We used a complex mobile laboratory equipped with a HACH Drel/2010 multi-parameter for the measurement of physico-chemical parameters: temperature $\left(\mathrm{T}\right.$ : $\left.{ }^{\circ} \mathrm{C}\right)$; $\mathrm{pH}$ ( $\mathrm{pH}$ units); Luminescent Dissolved Oxygen (LDO:

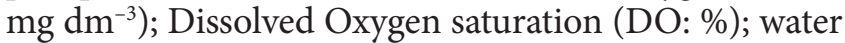
tension (U: $\mathrm{mV}$ ); Electrical Conductivity $\left(\mathrm{EC}: \mu \mathrm{S} \mathrm{cm} \mathrm{cm}^{-1}\right)$; Total Dissolved Solids concentration (TDS: $\mathrm{mg} \mathrm{dm}^{-3}$ ).

\section{Results and discussion}

Water circulation through Lake Erenciuc had become more efficient by the end of 1992 when river regulation of the Sfântu Gheorghe watercourse was begun. By regulating the branch, the navigation route shortened from $107 \mathrm{~km}$ to $74 \mathrm{~km}$ to facilitate the navigation and to avoid the clogging of the meandered sectors (Romanescu 2005). Due to river regulation and shortening the natural course of the branch, the main water velocity changed drastically. For this reason, water renewal in the lake is weaker. The main water supply is through the Erenciuc channel which links the lake with the branch. This direction of the water supply is dominant especially during the spring and early summer when the water levels in the branch are higher. By the end of the summer and during the autumn the direction of the water flow may change due to lower water levels in the watercourse and the waters from the lakes (including Lake Erenciuc) flow into the main branches.

The physico-chemical values are corelated with the water supply source but especially with the velocity of the supply. The differences between the values can be observed between the upstream sector (end of the lake), the middle sector and the downstream sector (the mouth of the lake). These must be corelated with the values recorded in sampling site 8 which corresponds with the waters in the main watercourse, Sfântu Gheorghe. The obtained data are compatible with those published in previous years, especially after the Sfântu Gheorghe branch was channeled over much of its length. The characteristic data from the Rosu-Puiu lacustrine complex, which supplies (through the waters from the Sulina branch) the Lake Erenciuc basin during summer and autumn were also taken into account (Romanescu 2005, 2006).

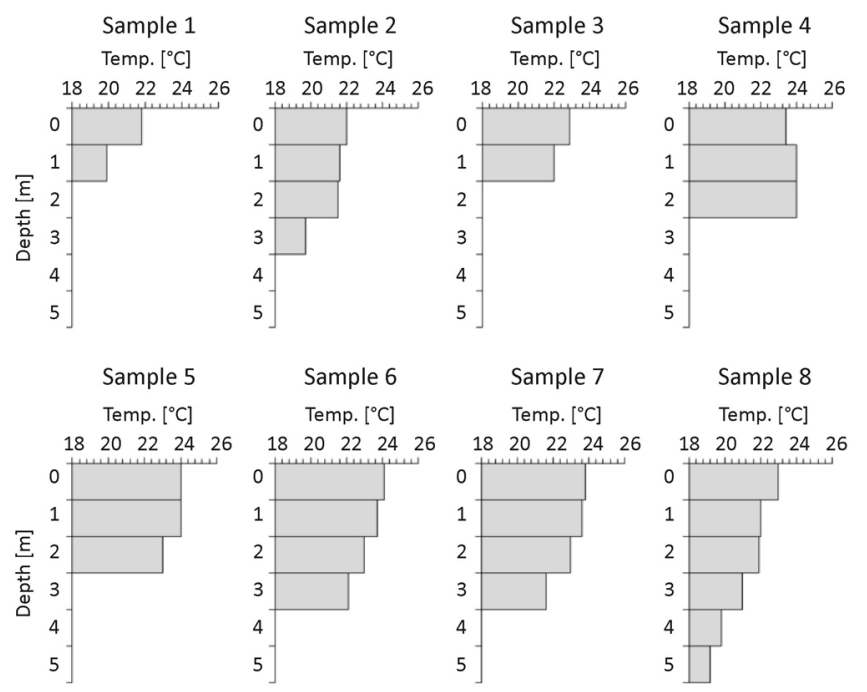

Fig. 3. Vertical distribution of water temperature, Temp. (in ${ }^{\circ} \mathrm{C}$ ) at eight sampling sites in Lake Erenciuc

The water surface temperature was relatively stable throughout all the sampling sites, including that one located at the main arm of River Danube (Sfântu Gheorghe branch). It ranged from 21.8 to $24.1^{\circ} \mathrm{C}$. This was due the fact that the water levels during the sampling campaign were higher than normal. Water temperature slowly decreased along depth gradient due to shallow conditions of the lake (Barbulescu 2015; Mihu-Pintilie et al. 2014). The maximum surface temperature $\left(24.1^{\circ} \mathrm{C}\right)$ was observed at site 6 (Fig. 3), while the minimum lake temperature was recorded at site $2\left(19.7^{\circ} \mathrm{C}\right)$ at 3 metres below the surface. Also, at site 1 water temperature near the bottom was below $20^{\circ} \mathrm{C}$, and dropped from $21.8^{\circ} \mathrm{C}$ at the surface to $19.9^{\circ} \mathrm{C}$ at the depth of 1 metre. In these two sampling sites the aquatic surface was covered with floating vegetation which blocked the light penetration into the water (Fig. 4). The air temperature throughout the day was identical with the water surface temperature.

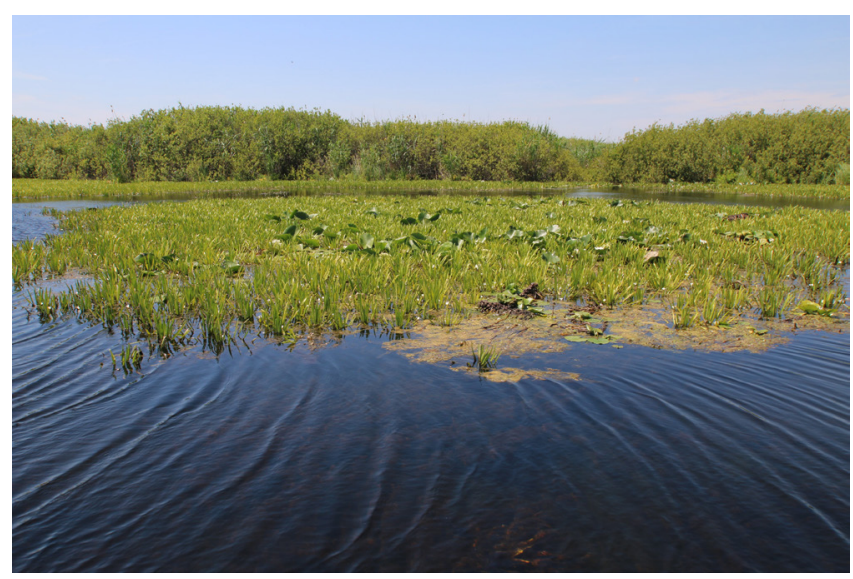

Fig. 4. The upstream part of Lake Erenciuc (the end of the lake) with aquatic and marsh vegetation 

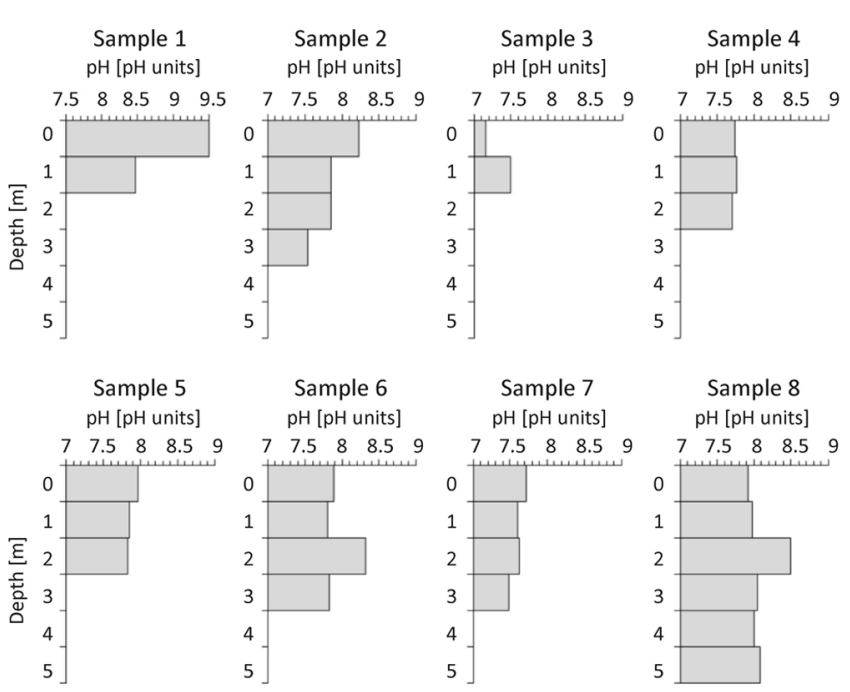

Fig. 5. Vertical distribution of $\mathrm{pH}$ (in $\mathrm{pH}$ units) at eight sampling sites in Lake Erenciuc

The lake waters are alkaline, and resemble those in the southern branch of the River Danube. The highest $\mathrm{pH}$ value (9.5 at the surface) was recorded in the upstream part of the lake (site 1), where the waters were stagnant due to the lack of surface water supply. In this sector the aquatic vegetation was abundant. The lowest $\mathrm{pH}$ (7.49 at a 3 metre depth) was recorded in the downstream part of the lake (mouth of the lake, site 7) and was almost identical with that in the Sfântu Gheorghe branch ( $\mathrm{pH}=7.92$ at the surface) (Fig. 5).

The highest values of dissolved oxygen concentration and oxygen saturation were recorded one metre below the water surface at sampling site $5\left(7.5 \mathrm{mg} \mathrm{dm}^{-3}\right.$, namely 90\%) (Fig. 6). They resemble those from the Sfântu Gheorghe branch (site 8), and favour the development of the biota. In turn, the lowest values were

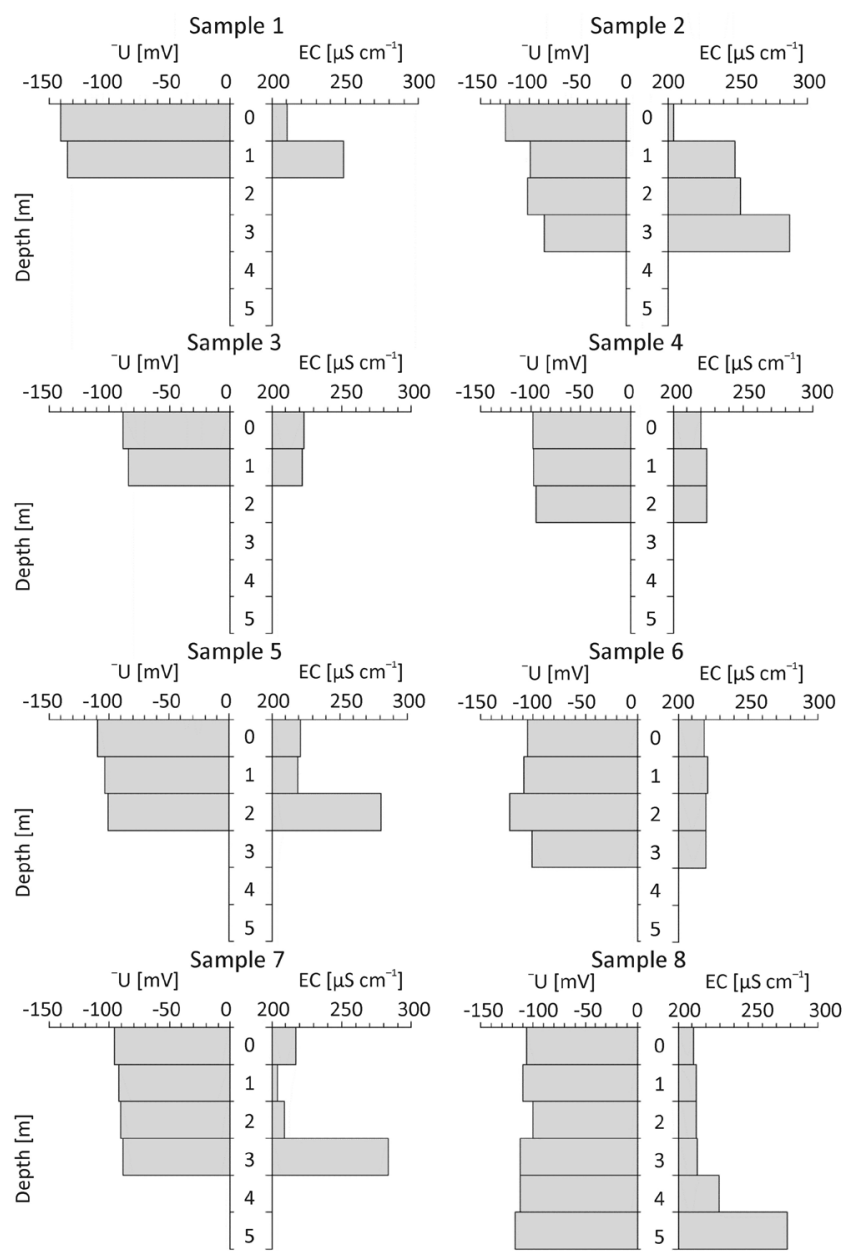

Fig. 7. Vertical distribution of water tension, $\mathrm{U}$ (in $\mathrm{mV}$ ) and electrical conductivity, EC [in $\mu \mathrm{S} \mathrm{cm}^{-1}$ ) at eight sampling sites in Lake Erenciuc
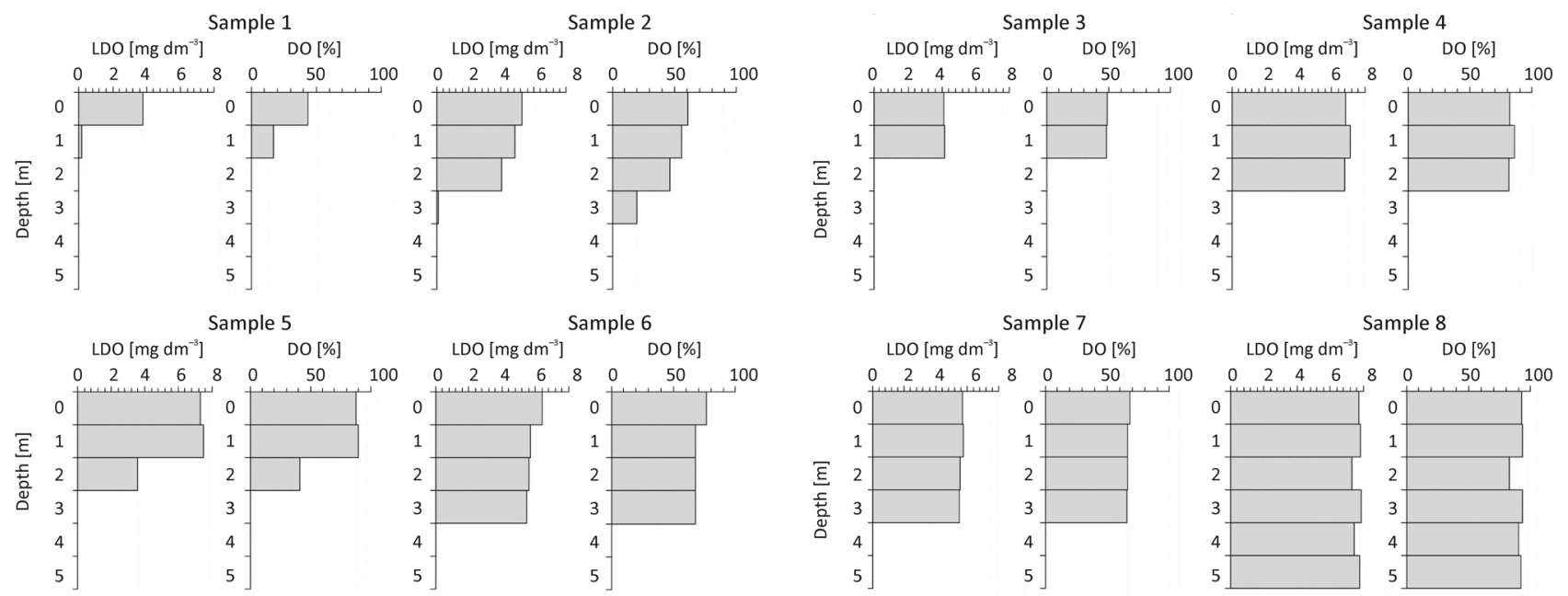

Fig. 6. Vertical distribution of dissolved oxygen concentration, LDO (in $\mathrm{mg} \mathrm{dm}^{-3}$ ) and dissolved oxygen saturation, DO (in percents) at eight sampling sites in Lake Erenciuc 


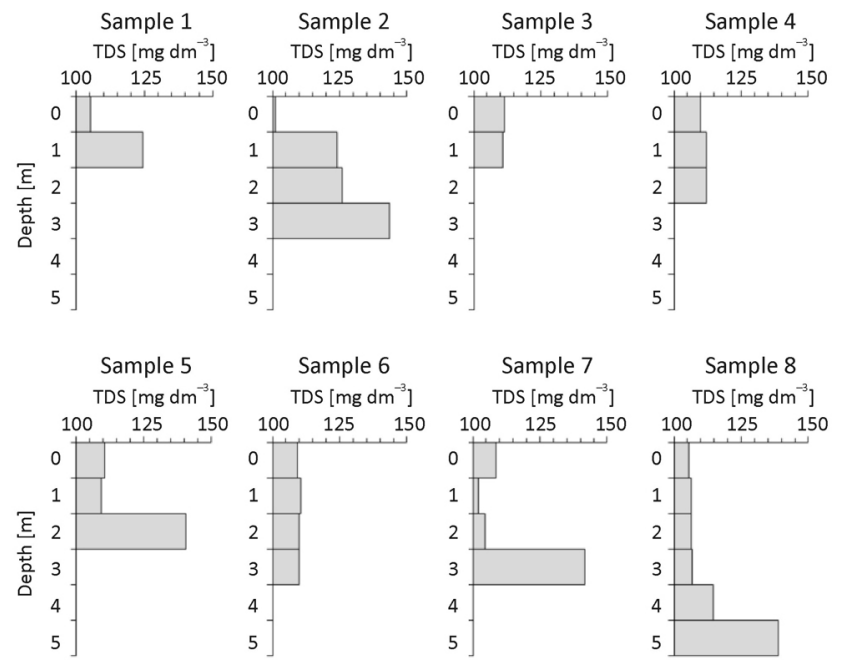

Fig. 8. Vertical distribution of total dissolved solids, TDS $\left(\mathrm{mg} \mathrm{dm}^{-3}\right)$ at eight sampling sites in Lake Erenciuc

recorded above the bottom at sampling sites 1 and 2 . Significantly worse oxygen conditions in the northwestern part of the lake (concentration: $0.11-0.15 \mathrm{mg}$ $\mathrm{dm}^{-3}$, and saturation: $\left.17-20 \%\right)$ are related to gas emissions from the decomposing organic substrate covering the lake bottom. In this part of the lake the organic clogging is dominant (above $80 \%$ ).

Characteristics of water tension and electrical conductivity (Fig. 7) were directly related to total dissolved solids concentration, TDS (Fig. 8). The highest TDS concentration $\left(143.5 \mathrm{mg} \mathrm{dm}^{-3}\right)$ was found at site 2 , at the depth of 3 meters. This was very close to the one observed in the near bottom layer in the Sfântu Gheorghe watercourse, where it reached $139.0 \mathrm{mg} \mathrm{dm}^{-3}$. The minimum TDS concentration was observed at a 2 metre depth at site $7\left(102.0 \mathrm{mg} \mathrm{dm}^{-3}\right)$, and was similar to the one measured in the surface water of the Sfântu Gheorghe (105.4 $\mathrm{mg} \mathrm{dm}^{-3}$ ).

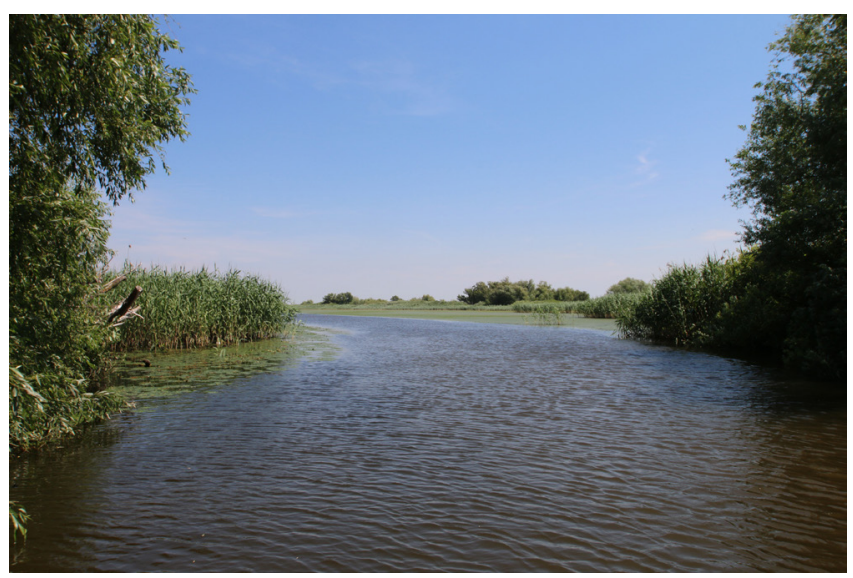

Fig. 9. Lake entry from Erenciuc channel (downstream sector)
Lake Erenciuc is a part of strictly protected area within the Danube Delta Biosphere Reserve. For this reason, anthropic interventions are limited to maintaining the permanent connection and sustaining water exchange with the Sfântu Gheorghe watercourse and with the nearby lake complex Puiu-Rosu (Fig. 9). The clogging rate of the flow channels is very high and due to the lack of water circulation there is a high risk of the lake eventually disappearing

\section{Conclusion}

Measurements during the high waters highlighted the existing connection between the lacustrine basins of the Erenciuc with the Sfântu Gheorghe branch. For this reason, the physical-chemical characteristics within the lake are similar to those within the main branch supplying it. During the low waters in the summer and fall, we feel the circulation within the delta, from the lacustrine complexes of Rosu-Puiu, and the direction of the current reverses. In this case, the physical-chemical characteristics of the waters are identical to those within the delta inlands. A good water supply exists only during the spring and early summer. By the end of the summer and in autumn the water levels in the branch drastically decrease, the lake is shallower and on several occasions the communication with the water from Sfântu Gheorghe watercourse are obstructed. During the high waters the eutrophication process is absent and this favors the evolution of biota. Thus, all the sampled parameters indicate a favourable status for the evolution of the biota.

\section{Acknowledgments}

Our sincerest gratitude goes to the Geo-archaeology Laboratory within the Faculty of Geography and Geology from the "Alexandru Ioan Cuza" University of Iaşi, which provided the equipment and processed the data.

\section{References}

Adopo K.L., Romanescu G., N'Guessan A.I., Stoleriu C., 2014, Relations between man and nature and environmental dynamics at the mouth of the Komoé river, Grand-Bassam (Ivory Coast), Carpath. J. Earth Environ. Sci. 9(4): 137-148.

Affonso A.G., Queiroz H.L., Novo E.M.L.M., 2011, Limnological characterization of floodplain lakes in Mamirauá Sustainable Development Reserve (Amazonas State, Brazil), Acta Limnol. Bras. 23(1): 95-108.

Allenbach K., Garonna I., Herold C., Monioudi I., Giuliani G., Lehmann A., Velegrakis A.F., 2015, Black Sea beaches vulnerability to sea level rise, Environ. Sci. Policy 46: 95-109. 
Amoros C., Bornette G., 2002, Connectivity and biocomplexity in water bodies or riverine floodplains, Freshw. Biol. 47(4): 761-776.

Andronache I., Fensholt R., Ahammer H., Ciobotaru A-M., Pintilii R-D., Peptenatu D., Draghici C.C., Diaconu D.C., Radulović M., Pulighe G., Azihou A.F., Toyi M.S., Sinsin B., 2017, Assessment of textural differentiations in forest resources in Romania using fractal analysis, Forests 8(3), 54: 1-20.

Anton M.C., Baltazar-Rojas M.M., Aluculesei A., Marguta R., Dorohoi D., 2008, Study regarding the water pollutionin in Romania and Spain, Rom. J. Phys. 53(1-2): 157-163.

Ashaary N.A., Wan Ishak W.H., Ku-Mahamud K.R., 2015, Forecasting the change of reservoir water level stage using neural network, Proc. of the 2nd International Conference on Mathematical Sciences and Computer Engineering (ICMSCE 2015), 5-6 February 2015, Langkawi: 103-107.

Barbulescu A., Barbes L., 2013, Assessment of Techirghiol Lake surface water quality using statistical analysis, Rev. Chim. (Bucharest) 64(8): 868-874.

Barbulescu A., 2015, Modeling temperature evaluation. Case study, Rom. Rep. Phys. 68(2): 788-798.

Barbulescu A., Maftei C., 2015, Modeling the climate in the area of Techirghiol Lake (Romania), Rom. J. Phys. 60(78): 1163-1170.

Banaduc D., Rey S., Trichkova T., Lenhardt M., Curtean-Banaduc A., 2016, The Lower Danube River-Danube DeltaNorth West Black Sea: A pivotal area of major interest for the past, present and future of its fish fauna. A short review, Sci. Total Environ. 545-546: 137-151.

Bayley P.B., 1995, Understanding large river-floodplain ecosystems, BioScience 45: 153-158.

Borowiak D., 2014, Optical properties of Polish lakes: the Secchi disc transparency, Limnol. Rev. 14(3): 131-144.

Burada A., Odor D.S., Teodorof L., Nastase C., Nastase A., Navodaru I., Georgescu L.P., 2014, Mercury levels in fish tissues with and without commercial value from Danube Delta Biosphere Reserve, J. Environ. Prot. Ecol. 15(3): 842-850.

Camargo A.F.M., Esteves F.A., 1996, Influence of water level variation on biomass and chemical composition of the aquatic macrophyte Eichhornia azurea (Kunth) in an oxbow lake of the Rio Mogi-Guacu (Sao Paulo, Brazil), Arch. Hydrobiol. 135(3): 423-432.

Catianis I., Radăn S., Grosu D., 2014, Loss of ignition as a proxy indicator for assessing the lithological composition of the recent sediments accumulated in some freshwater lakes from the Danube Delta, Romania, Int. J. Innov. Appl. Stud. (IJIAS) 9(1): 260-278.

Choi C., Han D., Kim J., Jung J., Kim D., Kim H.S., 2016, Mega flood simulation assuming successive extreme rainfall events, J. Wetlands Res. 18(1): 76-83.

Cical E., Mihali C., Mecea M., Dumuta A., Dippong T., 2016, Considerations on the relative efficacy of aluminium sulphates versus polyaluminium chloride for improving drinking water quality, Studia UBB Chemia 61(2): 225238.

Cirtina D., Capatina C., 2016, Assessment of physico-chemical characteristics and eutrophic parameters of Valea Mare and Turceni storage lakes, Rev. Chim. (Bucharest) 67(12): 2429-2434.

Cirtina D., Capatina C., 2017, Assessment of drinking water quality of Targu Jiu city by analyzing physical and chemical quality parameters, Rev. Chim. (Bucharest) 68(3): 439-446.

Coops H., Buijse L., Buijse A.D.T., Constantinescu A., Covaliov S., Hanganu J., Ibelings B.W., Menting F., Navodaru I., Oosterberg W., Staras M., Torok L., 2008, Trophic gradients in a large-river Delta: ecological structure determined by connectivity gradients in the Danube Delta (Romania), River Res. Appl. 24(5): 698-709.

Cudowski A., Gorniak A.S., Hryniewicka M., 2013, Boron and manganese fractions in dystrophic lake waters (Wigry National Park, NE Poland), Limnol. Rev. 13(2): 79-86.

Dawidek J., Ferencz B., 2012, Hydrological processes in the riverine Systems, the origin and classifications of floodplain lakes, Ekológia (Bratislava) 31(3): 331-340.

Dirtu D., Pancu M., Minea M.L., Chirazi M., Sandu I., Dirtu A.C., 2016, Study of the quality indicators for the indoor swimming pool water samples in Romania, Rev. Chim. (Bucharest) 67(6): 1167-1171.

Dragićević S., Živković N., Novković I., Petrović A., Tošić R., Milevski I., 2016, Hydrological and suspended sediment regime in the Kolubova River during the extreme year of 2014, Rev. Geomorf. (Bucharest) 18: 30-42.

Driga B.V., 2008, The hidrological relationship between Danube arms and lake complexis in the Danube delta, Lakes Reserv. Ponds 1-2: 61-71.

Forsberg B.R., 1984, Nutrient processing in Amazon floodplain lakes, Int. Ver. Theor. Angew. Limnol. Verh. 22: 1294-1298.

Furch K., 1984, Interannuelle variation hydrochemischer parameter auf der Ilha de Marchantaria, Biogeographica 19: 85-100.

Gadzinowska J., 2013, Plankton communities in oxbow lakes of the River Vistula (Oświęcim Basin) with bottom sediments heterogenously contamineted with heavy metals, Limnol. Rev. 13(2): 93-104.

García de Emiliani M.O., 1997, Effects of water level fluctuations on phytoplankton in a river floodplain lake system (Paraná River, Argentina), Hydrobiologia 357: 1-15.

Gâstescu P., Ştiucă R., 2008, Delta Dunării. Rezervație a biosferei (The Danube Delta. Biosphere reserve), Editura Dobrogea, Bucuresti, 498 pp (in Romanian, English summary).

Iordache M., Popescu L.R., Pascu L.F., Lehr C.,Ungureanu E.M., Iordache I., 2015, Evaluation of the quality of environmental factors, soil and water in the Parang Mountains, Romania, Rev. Chim. (Bucharest) 66(7): 1009-1014. 
Glińska-Lewczuk K., 2009, Water quality dynamics of oxbow lakes in young-glacial landscape of NE Poland in relation to their hydrological connectivity, Ecol. Engrg. 35(1): 25-37.

Junk W.J., Bayley P.B., Sparks R.E., 1989, The flood pulse concept in river-floodplain systems, [in:] Dodge D. P. [ed.] Proc. of the International Large River Symposium, Can. Spec. Publ. Fish. Aquat. Sci, 106: 110-127.

Keremedchiev S., Valchev N., 2008, Morphodynamic analysis of the coastal zone in the area of St. George sub-delta (Danube Delta) and the Sakalin Island (NW Black Sea), C. R. Acad. Bulg. Sci. 61(8): 1037-1046.

Kubiak J., Machula S., Choinski A., 2017, Particular example of meromixis in the anthropogenic reservoir, Carpath. J. Earth Environ. Sci. 13(1): 5-13.

Kundrát J.T., Simon E., Gyulai I., Lakatos G., Tóthmérész, B., 2016, Short-term weather fluctuation and quality assessment of oxbows, Idojaras 120(3): 301-313.

Lewis W.M., 1983, A revised classification of lakes based on mixing, Can. J. Fish. Aquat. Sci. 40: 1779-1787.

Marszelewski W., Dembowska E.A., Napiórkowski P., Solarczyk A., 2017, Understanding abiotic and biotic conditions in post-mining pit lakes for efficient management: A case study (Poland), Mine Water Environ. 36(3): 418-428.

Matenco L., Munteanu I., Borgh M., Stanica A., Tilita M., Lericolais G., Dinu C., Oaie G., 2015, The interplay between tectonics, sediment dynamics and gatways evolution in the Danube system from the Pannonian Basin to the western Black Sea, Sci. Total Environ. 543(Pt A): 807-827.

Melack J.M., 1984, Amazon floodplain lakes: Shape, fetch and stratyfication, Verh. Int. Ver. Limnol. 22: 1278-1282.

Merecki N., Agič R., Šunić L., Milenković L., Ilić Z.S., 2015, Transfer factor as indicator of heavy metals content in plants, Fresenius Envir. Bull. 24(11c): 4212-4219.

Mierlă M., Romanescu G., Nichersu I., Grigoras I., 2015, Hydrological risk map for the Danube delta: A case study of floods within the fluvial delta, IEEE J. Sel. Topics Appl. Earth Observ. Remote Sens. 8(1): 98-104.

Mierlă M., Nichersu I., Trifanov C., Nichersu Iuliana, Marin E., Sela F., 2014, Links between Selected Environmental Components and Flood Risk in the Danube Delta, Acta Zool. Bulg., Suppl. 7: 203-207.

Mihaiescu R., Pop A.I., Mihaiescu T., Muntean E., Beldean S., Munteanu N., Alhafez L., Ozun A., 2012, Physico-chemical characteristics of the karst Lake Ighiu (Romania), Environ. Eng. Manag. J. 11(3): 623-626.

Mihu-Pintilie A., Romanescu G., Stoleriu C., 2014, The seasonal changes of the temperature, $\mathrm{pH}$ and dissolved oxygen in the Cuejdel Lake, Romania, Carpath. J. Earth Environ. Sci. 9(2): 113-123.

Navodaru I., Staras M., Cernisencu I., 2001, The challenge of sustainable use of the Danube Delta Fisheries, Romania, Fish. Manag. Ecol. 8(4-5): 323-332.

Navodaru I., Staras M., Buijse A.D., Leeuw J.J., 2005, Changes in fish populations in Danube delta lakes: effects of hy- drology and water quality change. Review of results and potential for rehabilitation, Ecohydrol. Hydrobiol. 5(3): 245-256.

Pantea I., Ferechide D., Barbilian A., Lupusoru M., Lupusoru G.E., Moga M., Vilcu M.E., Ionescu T., Brezean I., 2017, Drinking water quality assessment among rural areas suplied by a centralized water system in Brasov county, UPB Sci. Bull., Series B 79(1): 61-70.

Pasztaleniec A., Karpowicz M., Strzalek M., 2013, The influence of habitat conditions on the plankton in the Biale oxbow lake (Nadbużanski Landscape Park), Limnol. Rev. 13(1): 43-50.

Payne A.L., 1986, The ecology of Tropical Lakes and Rivers, Wiley, Chichester, $301 \mathrm{pp}$.

Petrişor A.I., 2016, Assessment of the long-term effects of global changes within the romanian natural protected areas, Int. J. Conserv. Sci. (IJCS) 7(3): 759-770.

Petrişor A.I., Petre R., Meiţă V., 2016, Difficulties in achieving social sustainability in a biosphere reserve, Int. J. Conserv. Sci. (IJCS)7(1): 123-136.

Petrovici M., Balan S., Gruia R., Pop O.G., 2010, Diversity of macrozoobenthic community from fish farms as a consequence of the Fisheries amanagement, Environ. Eng. Manag. J. 9(12): 1589-1592.

Pop A.I., Mihaiescu R., Mihaiescu T., Oprea M.G., Tanaselia C. Ozunu A., 2013, Physico-chemical properties of some glacial lakes in the Romanian Carpathians, Carpath. J. Earth Environ. Sci. 8(4): 5-11.

Puri P.J., Yenkie M.K.N., Battalwar D.G., Gandhare N.V., Dhanorkar D.B., 2010, Study and interpretation of physicochemical characteristic of lake water quality in Nagpur city (India), Rasayan J. Chem. 3(4): 800-810.

Raischi M.C., Oprea L., Deak G., Badilita A., Tudor M., 2016, Comparative study on the use of new sturgeon migration monitoring systems on the lower Danube, Environ. Eng. Manag. J. 15(5): 1081-1085.

Romanescu G., 2003, Hidrologie generală (General hydrology), Editura Terra Nostra, Iaşi, 574 pp (in Romanian).

Romanescu G., 2005, Morpho-hydrographical evolution of the Danube Delta. Vol. 2: Management of water resources and coastline evolution. Land use and the ecological consequences, Editura Terra Nostra, Iaşi, 315 pp.

Romanescu G., 2006, Complexul lagunar Razim-Sinoie. Studiu morfohidrografic (Razim-Sinoie lagoon complex. Morphohidrographic study), Editura Universităţii “Alexandru Ioan Cuza”, Iaşi, 179 pp (in Romanian, English summary).

Romanescu G., 2013, Geoarchaeology of the ancient and medieval Danube Delta: Modeling environmental and historical changes. A review, Quat. Int. 293: 231-244.

Romanescu G., 2014, The catchment area of the Milesian colony of Histria, within the Razim-Sinoie lagoon complex (Romania): hydro-geomorphologic, economic and geopolitical implications, Area 46(3): 320-327.

Romanescu G., Cojocaru I., 2010, Hydrogeological considerations on the western sector of the Danube Delta: A 
case study for the Caraorman and Saraturile fluvial-marine levees (with similarities for the Letea levee), Environ. Eng. Manag. J. 9(6): 795-806.

Romanescu G., Pascal M., Pintilie Mihu A., Stoleriu C.C., Sandu I., Moisii M., 2017, Water quality alanysis in wetlands freshwater: Common floodplain of Jijia-Prut Rivers, Rev. Chim. (Bucharest) 68(3): 553-561.

Romanescu G., Sandu I., Stoleriu C., Sandu I.G., 2014, Water resources in Romania and their quality in the main lacustrine basins, Rev. Chim. (Bucharest) 65(3): 344-349.

Romanescu G., Stoleriu C., 2014, Seasonal variation of temperature, $\mathrm{pH}$ and dissolved oxygen concentration in Lake Rosu, Romania, CLEAN - Soil, Air, Water 42(3): 236242.

Romanescu G., Stoleriu C., 2014., Anthropogenic interventions and hydrological-risk phenomena in the fluvialmaritime delta of the Danube (Romania), Ocean Coast. Manage. 102: 123-130.

Rzymski P., Klimaszyk P., Marszelewski W., Borowiak D., Mleczek M., Nowiński K., Pius B., Niedzielski P., Poniedziałek B., 2017, The chemistry and toxicity of discharge waters from copper mine tailing impoundment in the valley of the Apuseni Mountains in Romania, Environ. Sci. Pollut. Res. Int. 24(26): 21445-21458.

Sevianu E., Stermin A.N., Malos C., Reti K., Munteanu D., David A., 2015, GIS modeling for the ecological restoration of a nature reserve: Legii lake and valley (NW Romania): A case study, Carpath. J. Earth Environ. Sci. 10(4): $173-180$.

Sioli H., 1984, The Amazon and its main affluents: hydrography, morphology of the river courses, and river types, [in:] Sioli H., (ed.), The Amazon: limnology and landscape ecology of a mighty tropical river and its basin, Junk W., Dordrecht: 127-165.

Stefan D.S., Neacsu N., Pincovschi I., Stefan M., 2017, Water quality and self-purification capacity assessment of Snagov Lake, Rev. Chim. (Bucharest) 68(1): 60-64.

Su X., Nilsson C., Pilotto F., Liu S., Shi S., Zeng B., 2017, Soil erosion and deposition in the new shorelines of the Three Gorges Reservoir, Sci. Total Environ. 599-600: 14851492.

Sundri M.I., 2015, Danube zooplankton diversity in Cernavoda area, Analele Univ. Mar. Constanta 16(23): 81-86.

Telteu C.E., Zaharia L., 2012, Morphometrical and dynamical features of the South Dobrogea lakes, Romania, Procedia Environ. Sci. 14: 164-176.
Ten Brinke W.B.M., Knoop J., Muilwijk H., Ligtvoet W., 2017, Social disruption by flooding, a European perspective, Int. J. Disaster Risk Reduct. 21: 312-322.

Thoms M.C., 2003, Floodplain-river ecosystems: lateral connections and the implications of human interference, Geomorphology 56(3-4): 335-349.

Tockner K., Malard F., Ward J.V., 2000, An extension of the flood pulse concept, Hydrol. Process. 14(16): 2861-2883.

Tockner K., Malard F., Uehlinger U., Ward J.V., 2002, Nutrients and organic matter in a glacial river-floodplain system (Val Roseg, Switzerland), Limnol. Oceanogr. 47(1): 266-277.

Tokar A., Negoitescu A., Hamat C., Rosu S., 2016, The chemical and ecological state evaluation of a storage lake, Rev. Chim. (Bucharest) 67(9): 1860-1863.

Türk G., Bertalan L., Balázs B., Baranyai E.F., Szabó S., 2016, Process of overturning due to a floodwave in an oxbow lake of Tisza river, Carpath. J. Earth Environ. Sci. 11(1): 255-264.

Ureche D., Ureche C., Lazar I.M., 2012, Length-weight relationship and fulton's condition factor for nine species of fish captured from the basin of river Casin including some of its tributaries, Environ. Eng. Manag. J. 11(12): 2275-2283.

Van Dinter M., 2017, Living along the Limes. Landscape and settlement in the Lower Rhine Delta during Roman and Early Medieval times [Dissertation], Utrecht Studies in Earth Sciences 135: 1-221.

Van Leeuwen B., Pravetz T., Liptay Z.A., Tobak Z., 2016, Physically based hydrological modelling of inland excess water, Carpath. J. Earth Environ. Sci. 11(2): 497-510.

Vespremeanu-Stroe A., Zainescu F., Preoteasa L., Tatui F., Rotaru S., Morhange C., Stoica M., Hanganu F., TimarGabor A., Cardan I., Piotrowska N., 2017, Holocene evolution of the Danube delta: An integral reconstuction and an revised chronology, Mar. Geol. 388: 38-61.

Wrzesiński D., Choiński A., Ptak M., Skowron R., 2015, Effect of the North Atlantic Oscillation on the pattern of lake ice phenology in Poland, Acta Geophys. 63(6): 1664-1684.

Wu S., Wiessner A., Braeckevelt M., Kappekmeyer U., Ding R., Müller J., Kuschk P., 2013, Influence of nitrate load on sulfur transformations in the rhizosphere of Juncus effusus in laboratory-scale constructed wetlands treating artificial domestic wasewater, Environ. Eng. Manag. J. 12(3): 565-573.

Yang H.C., Wang C.Y., Yang J.X., 2014, Applying image recording and identification for measuring water stages to present flood hazards, Nat. Hazards 74(2): 737-754. 